\title{
Knowledge management processes and innovation performance: The moderating effect of em- ployees' knowledge hoarding
}

\author{
Lina Al-Abbadia ${ }^{*}$, Rawan Alshawabkeh ${ }^{a}$ and Amani Abu Rumman ${ }^{\mathrm{a}}$
}

\begin{tabular}{l}
${ }^{a}$ AL-Ahliyya Amman University, Jord \\
\hline C H R O N I C L E \\
\hline Article history: \\
Received: November 12, 2019 \\
Received in revised format: No- \\
vember 302019 \\
Accepted: December 18, 2019 \\
Available online: \\
December 18, 2019 \\
\hline Keywords: \\
Knowledge management \\
Innovation performance \\
Knowledge hoarding
\end{tabular}

\section{Introduction}

Effective and efficient organizations seek to exploit every source that helps achieve a sustainable competitive advantage. One pivotal source to attain that, is knowledge management (KM) which is designed to acquire, disseminate, share and apply knowledge (Karamat et al., 2018). Knowledge must be one of the organizational sources that organizations need to possess (Mahdi et al., 2019). In view of the effectiveness of achieving the objective of KM, other factors must be considered to achieve this end. An example of these hindering factors is knowledge hoarding (Bilginoğlu, 2019). It is common for organizations to pay attention to interventions at organizational level, technology, and relationships in order to obtain a value, in parallel with the belief in the need for effective management of the knowledge held by the organization in general, and employees in particular (Barley et al., 2018). The importance of knowledge management practices or processes can be seen by recognizing their impact on many variables as found in KM literature. Some examples of researchers' findings in this context showed that knowledge transfer activities have a significant and positive effect on supply chain flexibility (Blome et al., 2014), tacit knowledge was positively associated with innovation success (Seidler-de Alwis \& Hartmann, 2008), KM processes have a

* Corresponding author

E-mail address: linahamdanabbadi@yahoo.com (L. Al-Abbadi)

(C) 2020 by the authors; licensee Growing Science, Canada

\footnotetext{
doi: $10.5267 /$ j.msl.2019.12.021
} 
significant influence on organizational performance (Rasula et al., 2012). Studies have also shown that knowledge management is reflected in the application of other important trends such as customer relationship management (Srivastava et al., 2019). A review of the literature emphasized the interest of researchers in studying the relationship between knowledge management, regardless of its dimensions, and innovation performance (Darroch, 2005; Chen \& Huang, 2009; Kör \& Maden, 2013; Chapman et al., 2006; Mundra et al., 2011; Alegre et al., 2011; Salem, 2014; Al-Husseini \& Elbeltagi, 2015; Obeidat et al., 2016; Alegre et al., 2011; Arshad \& Ismail, 2018). Those studies picked up an evidence of a positive influence of KM on innovation. Despite the importance of the findings of previous studies, however, the present study is the first in terms of testing the moderating role of knowledge hoarding on the effect of knowledge management on innovation performance. The contribution of the study to literature lies in this important point that organizations ignore.

\section{Literature review}

\subsection{Knowledge management}

$\mathrm{KM}$ has been defined as a set of knowledge-related practices such as knowledge creation and distribution (Mundra et al., 2011) with a purpose of improving organizational performance including innovation performance which capitalizes on new ideas (Alegre et al., 2011). A recent view described KM as a set of activities that stimulate individuals' behavior so that it leads to innovation (Loon, 2019). Authors used several dimensions to measure knowledge management, including knowledge acquisition, knowledge dissemination and responsiveness to knowledge (Darroch, 2005), knowledge acquisition, knowledge sharing and knowledge application (Chen \& Huang, 2009), knowledge creation, organizing, storage, sharing and utilization (Iqbal, 2011), knowledge dissemination and knowledge storage (Alegre et al., 2011), knowledge acquisition, conversion, application, and protection (Salem, 2014), knowledge acquisition, knowledge sharing, and knowledge utilization (Obeidat et al., 2016), knowledge identification, creation, collection, organizing, dissemination, storage, and application (Masa'deh et al., 2017). These dimensions were re-exhibited in Table 1.

Table 1

Dimensions of KM

\begin{tabular}{|c|c|}
\hline KM Dimensions & Researchers \\
\hline Knowledge acquisition, dissemination, and responsiveness to knowledge & Darroch (2005) \\
\hline Knowledge acquisition, sharing, and application & Chen and Huang (2009) \\
\hline Knowledge sharing, and knowledge application & Li et al. (2009) \\
\hline Knowledge creation, organizing, storage, sharing and utilization & Iqbal (2011) \\
\hline Knowledge dissemination, storage, and acquisition & Alegre et al. (2011) \\
\hline Knowledge application and knowledge sharing & Kör and Maden (2013) \\
\hline Knowledge acquisition, conversion, application, and protection & Salem (2014) \\
\hline Knowledge acquisition, sharing, and utilization & Obeidat et al. (2016) \\
\hline Knowledge identification, creation, collection, organizing, dissemination, storage, and application & Masa'deh et al. (2017) \\
\hline Knowledge generation, storage, sharing, and application & Mahdi et al. (2019) \\
\hline
\end{tabular}

\subsection{Knowledge hoarding}

Knowledge hoarding has been defined as employee's perception that his or her knowledge is in fact a private intellectual capital, and therefore he or she refuses to share it with others in the organization. There is a difference between knowledge hiding and knowledge hoarding. Hiding knowledge is to refuse to give it to others while they are asking for it, while knowledge hoarding is the accumulation of knowledge right now, but it is possible that this knowledge will be shared in the future (Bilginoğlu, 2019). While knowledge sharing is a positive aspect of knowledge management, knowledge hoarding is a negative aspect (Holten et al., 2016).

Anaza and Nowlin (2017) used the theory of knowledge stickiness to study the behavior of knowledge hoarding, which relates to the interruption of knowledge flow in the organization because of the employee's refusal to share knowledge. The authors indicated that this theory has been utilized to explain the problems of knowledge transfer and technical innovation. According to du Plessis (2005) and Yang (2007), knowledge hoarding can be described as a syndrome of "knowledge is power", therefore, employees refuse to share this power with others. In terms of knowledge hoarding measurement, no specified dimensions utilized by researchers to assess this variable. Connelly et al. (2012) used four items to evaluate this variable related to information accumulating as a stockpile that the employee might use in the future. Holten et al. (2016) used one item to evaluate the extent to which the employee exercises knowledge hoarding, where a question was asked to respondent about the occurrence of this behavior. 


\subsection{Innovation performance}

Innovation performance has been defined as a process of implementing creative ideas (Iqbal, 2011). Several dimensions were used to evaluate innovation performance as shown in Table 2. Salem (2014) measured innovation base on innovation speed and innovation magnitude. Innovation speed relates to generation of processes, products and services quickly, while innovation magnitude describes the number of processes, products and services generated. Gloet and Terziovski (2004) evaluated innovation based quality and responsiveness, while numerous studies used technological, administrative, radical and incremental innovations to assess innovation performance (Chen \& Huang, 2009; Iqbal, 2011; Kör \& Maden, 2013).

Table 2

Dimensions of IP

\begin{tabular}{|c|c|}
\hline IP Dimensions & Researchers \\
\hline $\begin{array}{l}\text { Process improvement, product, quality of process, product and service, and lead- } \\
\text { time innovation }\end{array}$ & Gloet and Terziovski (2004) \\
\hline Administrative innovation and technical innovation & Chen and Huang (2009) \\
\hline Technological, administrative, radical, and incremental innovation & Iqbal (2011) \\
\hline Administrative innovation and technical innovation & Kör and Maden (2013) \\
\hline Innovation speed and innovation magnitude & Salem (2014) \\
\hline
\end{tabular}

\subsection{Hypotheses development}

\section{Knowledge management and innovation performance}

An evidence on the positive effect of knowledge management dimensions on innovation has been established in a number of studies. Darroch (2005) examined the effect of knowledge management as measured by knowledge acquisition, knowledge dissemination and responsiveness to knowledge on innovation and organizational performance based on data collected from senior participants selected from organizations with more than 49 employees and found that knowledge acquisition, knowledge dissemination and responsiveness to knowledge had a positive impact on innovation. Chen and Huang (2009) investigated the effect of strategic human resources practices on innovation performance through knowledge management capacity gathering data from top management participants and supported the hypothesis that KM capacity mediated the effect of strategic human resources practices on innovation performance. Kör and Maden (2013) studied the mediating role of innovativeness in the effect of knowledge management and innovation in service and high-tech organizations on the ground of data extracted from executive managers and employees and provided an evidence that innovativeness partially mediated the effect of knowledge management on innovation. From top and middle managers' point of view, Rezaei et al. (2018) highlighted that knowledge creation is positively related to technological and administrative innovation. Salem (2014) carried out a study on five-star hotels in Egypt and found a significant effect of KM processes (knowledge acquisition, conversion, application, and protection) on hotel innovation. Obeidat et al. (2016) conducted a study on consultancy firms in Jordan and showed a positive effect of KM processes (knowledge acquisition, sharing, and utilization) on innovation. In a study on higher education institutions, Al-Husseini and Elbeltagi (2015) found that knowledge sharing has a significant effect on innovation.

According to Mauri-Castello et al. (2019), innovation implementation is a process that depends on understanding customer needs in accordance with products, environment, sector and KM. It was derived that Knowledge is one of the most important organizational sources and knowledge management that has a positive effect on innovation. Chapman et al. (2006: 129) argued that "knowledge is a key component of all forms of innovation". For the purpose of recognizing the effect of KM practices on innovation from managers' perspectives, five key hypotheses as shown in Figure 1were introduced:

H1: Knowledge acquisition exerts a positive influence on innovation performance.

$\mathrm{H} 2$ : Knowledge dissemination exerts a positive influence on innovation performance.

H3: Knowledge storage exerts a positive influence on innovation performance.

H4: Knowledge sharing exerts a positive influence on innovation performance.

H5: Knowledge application exerts a positive influence on innovation performance.

\section{Knowledge management, knowledge hoarding and innovation performance}

The relationship between KM processes and knowledge hoarding, on the one hand, as well as the knowledge hoarding and innovation performance, on the other hand, is still unclear. However, Scarbrough (2003) indicated that knowledge management helps to eliminate obstacles to innovation such as knowledge hoarding. This means that there is a negative effect of knowledge hoarding on innovation performance and this can be achieved through knowledge management processes. 


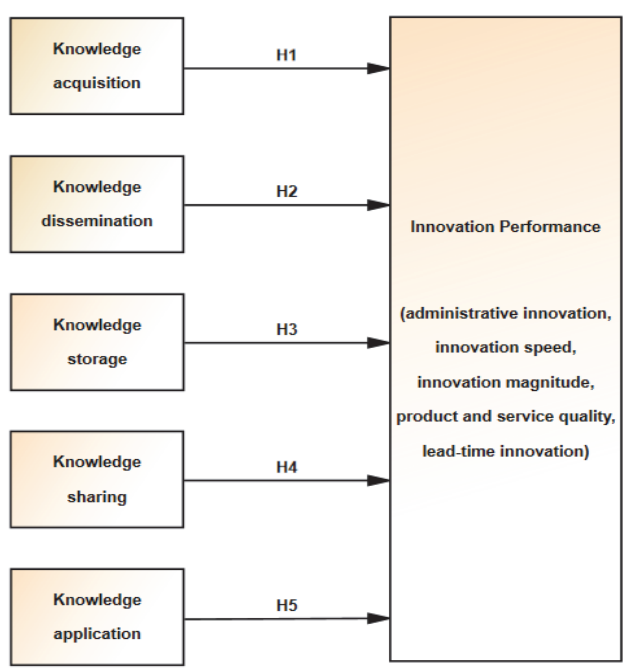

Fig. 1. Perceptual model of hypothesis H1-H5

Donate and de Pablo (2015) discussed the importance of leadership style and knowledge management and indicated that the leadership style can reduce the effectiveness of knowledge management processes, as that style may lead to increased knowledge hoarding behavior. This also underscores the negative role played by knowledge hoarding in KM processes. Aulawi et al. (2009) added that KM processes, such as knowledge sharing, dissemination and application are of great importance to the organization, and its significance stems from the fact that it enhances innovation performance. Prabhakar et al. (2018) confirmed that knowledge hoarding adversely affects the effectiveness of KM. However, the relationship between KM and innovation may not go unnoticed, with negative behaviors such as knowledge hoarding. Based on these results, it was presumed, as shown in Fig. 2, we propose

$\mathbf{H}_{6}$ : Knowledge hoarding moderates the effect of KM processes on innovation performance.

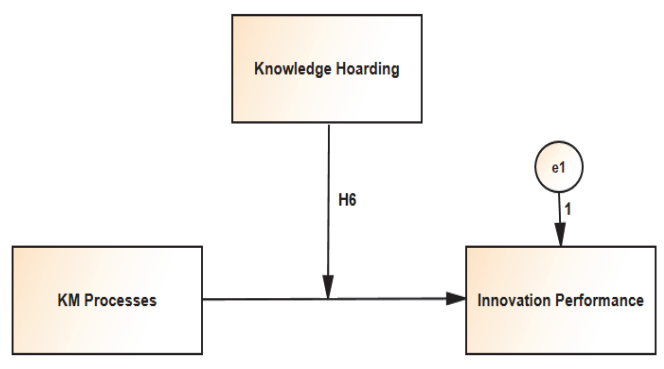

Fig. 2. Perceptual model of moderation hypothesis (H6)

\section{Methodology}

\subsection{Sample and data collection}

The population of the study consisted of managers working at 20 commerce and service organizations. From each organization, 20 managers were selected. Therefore, the sample of the study contained 400 managers. Data were collected by a selfadministered questionnaire. Four-hundred questionnaires were distributed, and 314 questionnaires were returned with a response rate of $78.5 \%$.

\subsection{Measures}

Table 3 illustrates measurements used in the current study to evaluate constructs. Knowledge acquisition was measured via three items adapted from Salem (2014); collecting knowledge about customers, obtaining knowledge about customers using existing knowledge to generate new knowledge, and gathering information about new products or services in the market. Knowledge dissemination was measured based on Alegre et al. (2013) by asking respondents to rate the extent to which some practices are used in their organizations. These practices are concerned with availability of mechanisms used by the organization to increase information sharing, information distribution systems in the organization, and techniques of employees' participation like improving groups. Knowledge storage was assessed by three items adapted from Donate and de Pablo (2015), 
which were storage of customer information in updated databases, possibility of access to information within the organization, and organization's behavior in codifying or documenting information.

Table 3

Measurements used to assess variables in the current study

\begin{tabular}{llll}
\hline Variables & Dimensions (items) & Items & Author (s) \\
\hline \multirow{4}{*}{$\begin{array}{l}\text { KM pro- } \\
\text { cesses }\end{array}$} & Knowledge acquisition & KM1 & Salem (2014) \\
& Knowledge dissemination & KM2 & Alegre et al. (2013) \\
& Knowledge storage & KM3 & Donate and de Pablo (2015) \\
& Knowledge sharing & KM4 & Garrido-Moreno and Padilla-Meléndez (2011) \\
& Knowledge application & KM5 & Donate and de Pablo (2015) \\
\hline \multirow{2}{*}{$\begin{array}{l}\text { Employee } \\
\text { knowledge } \\
\text { hoarding }\end{array}$} & Knowledge accumulation & KH1 & Anaza and Nowlin (2017) \\
& Knowledge share refuse & KH2 & Birkinshaw and Sheehan (2002), Husted and Michailova \\
& "Knowledge is power" syndrome & KH3 & Du Plessis (2005) \\
\hline \multirow{4}{*}{$\begin{array}{l}\text { Innovation } \\
\text { performance }\end{array}$} & Administrative innovation & IP1 & Chen and Huang (2009) \\
& Innovation speed & IP2 & Salem (2014) \\
& Innovation magnitude & IP3 & Salem (2014) \\
& Product and service quality & IP4 & Sadikoglu and Zehir (2010) \\
& Lead-time innovation & IP5 & Sadikoglu and Zehir (2010) \\
\hline
\end{tabular}

Knowledge sharing was measured by three items adopted from Garrido-Moreno and Padilla-Meléndez (2011), which related to organizational environment that promotes knowledge sharing, organizational culture that supports knowledge sharing, and organizational processes designed by the organization to achieve this end. Three items were adapted from Donate and de Pablo (2015) to measure knowledge application in terms of incorporation of customers and employees' suggestions as to organization's processes, products or services, preparing created knowledge for new uses, and employee access to knowledge within the organization. Knowledge hoarding was measured via six items related to knowledge accumulation by employees, and knowledge share refuse, as well as a syndrome of "knowledge is power" that leads employees to hoard knowledge. These items were adapted from Birkinshaw and Sheehan (2002), Husted and Michailova (2002), du Plessis (2005) and Anaza and Nowlin (2017). Finally, innovation performance was measured by innovation speed, innovation magnitude, administrative innovation, product and service quality and lead-time innovation. Innovation speed items were adapted from Salem (2014); organization speed in generating new ideas, developing products or services, and launching of new products. Innovation magnitude items were also adapted from Salem (2014) in terms of organization ability to produce many new ideas and products or services as well as decisions. Administrative innovation was measured based on Chen and Huang (2009) to reflect organization innovation in planning procedures and control systems as well as organization response to changes in the surrounded environment. Product and service quality and lead-time innovation were measured through four items adapted from Sadikoglu and Zehir (2010) in order to estimate customers satisfaction with products or service quality that at least meet their expectations. Leadtime was also measured by items related to delivery of purchased materials to the organization and delivery of products or services to customers.

\section{Data analysis and results}

\subsection{Multicollinearity}

Variance inflation factor (VIF) and tolerance were used to examine multicollinearity between independent variables. According to Robinson and Schumacker (2009), multicollinearity between independent variables is possible if these variables are introduced in the regression model. VIF values should not exceed the value of 10 and tolerance should be greater than 0.1 . The results showed that the data used in this study were free from multicollinearity problem (VIF $=1.242$, tolerance $>0.1$ ). This result indicates that regression coefficients in the current study model are stable (Yoo \&Donthu, 2001).

\subsection{Validity and reliability}

Convergent validity was examined by average variance extracted (AVE) and discriminant validity was verified by the square root of the average variance extracted (VAVE) (Bock et al., 2005). According to Fornell and Larcker (1981), discriminant validity is accepted when the square root of AVE is higher than correlation coefficient between the variable and other variables. Reliability was tested by Cronbach's alpha coefficient $(\alpha)$. An acceptable value of alpha has been identified as being greater than 0.70 (Santos, 1999). The results in Table 4 showed that factor loadings of all items were higher than 0.5 (Bock et al., 2005), average variance extracted values were greater than 0.7 and values of square root of the average variance extracted were greater than the correlation coefficient between each variable and other variables (Fornell \& Larcker, 1981) and Coefficients Cronbach's alpha exceeded 0.7 (Santos, 1999). Therefore, validity and reliability of all items were ensured. 
Table 4

Results of validity and reliability tests

\begin{tabular}{|c|c|c|c|c|c|c|}
\hline Variables & Dimensions & Items & Loadings & AVE & $\sqrt{A V E}$ & $\alpha$ \\
\hline \multirow{15}{*}{ KM processes } & \multirow{3}{*}{ Knowledge acquisition } & KM1-1 & 0.852 & \multirow{3}{*}{0.71} & \multirow{3}{*}{0.50} & \multirow{3}{*}{0.86} \\
\hline & & KM1-2 & 0.873 & & & \\
\hline & & KM1-3 & 0.799 & & & \\
\hline & \multirow{3}{*}{ Knowledge dissemination } & KM2-1 & 0.889 & \multirow{3}{*}{0.71} & \multirow{3}{*}{0.50} & \multirow{3}{*}{0.86} \\
\hline & & KM2-2 & 0.798 & & & \\
\hline & & KM2-3 & 0.839 & & & \\
\hline & \multirow{3}{*}{ Knowledge storage } & KM3-1 & 0.869 & \multirow{3}{*}{0.72} & \multirow{3}{*}{0.52} & \multirow{3}{*}{0.87} \\
\hline & & KM3-2 & 0.844 & & & \\
\hline & & KM3-3 & 0.829 & & & \\
\hline & \multirow{3}{*}{ Knowledge sharing } & KM4-1 & 0.877 & \multirow{3}{*}{0.73} & \multirow{3}{*}{0.53} & \multirow{3}{*}{0.88} \\
\hline & & KM4-2 & 0.858 & & & \\
\hline & & KM4-3 & 0.827 & & & \\
\hline & \multirow{3}{*}{ Knowledge application } & KM5-1 & 0.873 & \multirow{3}{*}{0.74} & \multirow{3}{*}{0.54} & \multirow{3}{*}{0.88} \\
\hline & & KM5-2 & 0.865 & & & \\
\hline & & KM5-3 & 0.834 & & & \\
\hline \multirow{6}{*}{$\begin{array}{l}\text { Employee knowledge } \\
\text { hoarding }\end{array}$} & \multirow{2}{*}{ Knowledge accumulation } & KH1-1 & 0.873 & \multirow{2}{*}{0.73} & \multirow{2}{*}{0.53} & \multirow{2}{*}{0.83} \\
\hline & & KH1-2 & 0.832 & & & \\
\hline & \multirow{2}{*}{ Knowledge share refuse } & $\mathrm{KH} 2-1$ & 0.891 & \multirow{2}{*}{0.75} & 0.56 & 084 \\
\hline & & $\mathrm{KH} 2-2$ & 0.837 & & & 0.04 \\
\hline & "Knowledge is power" syndrome & KH3-1 & 0.861 & 0.73 & 0.54 & 0.83 \\
\hline & 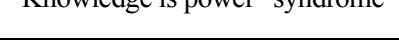 & $\mathrm{KH} 3-2$ & 0.852 & 0.13 & 0.04 & $0.0 \mathrm{~J}$ \\
\hline & & IP1-1 & 0.865 & & & \\
\hline & Administrative innovation & IP1-2 & 0.884 & 0.76 & 0.575 & 0.92 \\
\hline & & IP1-3 & 0.859 & & & \\
\hline & & IP2-1 & 0.876 & & & \\
\hline & Innovation speed & IP2-2 & 0.859 & 0.74 & 0.55 & 0.91 \\
\hline & & IP2-3 & 0.849 & & & \\
\hline $\begin{array}{l}\text { Innovation pertor- } \\
\text { mance }\end{array}$ & & IP3-1 & 0.855 & & & \\
\hline & Innovation magnitude & IP3-2 & 0.866 & 0.72 & 0.51 & 0.91 \\
\hline & & IP33 & 0.818 & & & \\
\hline & Product and service quality & IP4-1 & 0.877 & 0.75 & 0.56 & 0.84 \\
\hline & & IP4-2 & 0.854 & & & \\
\hline & Lead-time innovation & IP5-1 & 0.864 & 0.73 & 0.53 & 0.83 \\
\hline & & IP5-2 & 0.843 & & & \\
\hline
\end{tabular}

\subsection{Hypotheses H1-H5 testing}

Hypotheses H1-H5 postulated that KM dimensions (knowledge acquisition, dissemination, storage, sharing and application) exert positive influences on innovation performance. The results indicated that KM dimensions explained $19.4 \%\left(R^{2}=0.194\right)$ of the variance in the dependent variable (innovation performance). It was revealed that KM dimensions significantly predicted innovation performance $(\mathrm{F}=23.4, \mathrm{P}<0.05)$ with coefficients ranged from 0.161 to 0.248 . Therefore, hypotheses $\mathrm{H} 1$-H5 were supported as shown in Table 5. Knowledge sharing has the largest influence on innovation performance $(\beta=0.248, P<0.05)$, followed by knowledge application $(\beta=0.221, \mathrm{P}<0.05)$, knowledge storage $(\beta=0.210, \mathrm{P}<0.05)$, knowledge acquisition $(\beta=$ $1.790, \mathrm{P}<0.05)$, and finally, knowledge dissemination $(\beta=0.210, \mathrm{P}<0.05)$.

Table 5

Multiple regression analysis

\begin{tabular}{|c|c|c|c|c|c|c|c|}
\hline \multicolumn{2}{|c|}{ Model summary } & \multicolumn{2}{|c|}{ ANOVA } & \multirow{2}{*}{ IVs } & \multicolumn{3}{|c|}{ Coefficients } \\
\hline $\mathrm{R}$ & $\mathrm{R} 2$ & $\mathrm{~F}$ & $\mathrm{P}$ & & $\beta$ & $\mathrm{t}$ & $\mathrm{P}$ \\
\hline \multirow{5}{*}{0.44} & \multirow{5}{*}{0.194} & \multirow{5}{*}{23.4} & \multirow{5}{*}{0.000} & KM1 & 1.790 & 3.10 & 0.000 \\
\hline & & & & KM2 & 0.161 & 3.29 & 0.006 \\
\hline & & & & KM3 & 0.210 & 3.35 & 0.000 \\
\hline & & & & KM4 & 0.248 & 3.81 & 0.025 \\
\hline & & & & KM5 & 0.221 & 3.60 & 0.014 \\
\hline
\end{tabular}




\subsection{Hypothesis H6 testing}

Hypothesis 6 suggested that knowledge hoarding moderates the effect of KM processes on innovation performance. The structural equation modeling via AMOS 22.0 was used to test the hypothesis. The structural model was validated and tested following Lin (2007) and Okur and Saricam (2019). First, the goodness-of-fit of the hypothesized model was tested using Chi-square to degree of freedom ratio $\left(\chi^{2} / \mathrm{df}\right)$, the goodness of fit index (GFI), the comparative fit index (CFI) and the root mean square error of approximation (RMSEA). Second, the significance of the model paths was estimated as shown in Figure 3 . The results of the first step are outlined in Table 6. It was clarified that the structural model is adequate in terms of goodness-of-fit indices; $\chi^{2} / \mathrm{df} \leq 5, \mathrm{CFI} \geq 0.90, \mathrm{RMSEA} \leq 0.08$ (Chiu et al., 2006) and GFI $\geq 0.90$ (Sivo et al., 2006).

Table 6

Goodness-of-fit results

\begin{tabular}{cccc}
\hline Index & Value & Cut-off* & Result \\
\hline$\chi^{2 / \mathrm{df}}$ GFI & 1.87 & $\leq 5$ & Adequate \\
CFI & 0.922 & $\geq 0.90$ & Adequate \\
RMSEA & 0.918 & $\geq 0.90$ & Adequate \\
\hline
\end{tabular}

* Chiu et al. (2006) and Sivo et al. (2006).

Table 7 shows the results of the second step, in which KM processes were found to exert a significant positive effect on innovation performance (Estimate $=0.367$, C.R. $=3.17, \mathrm{P}=0.000$ ), knowledge hoarding exert a significant negative effect on innovation performance $($ Estimate $=0.228$, C.R. $=2.14, \mathrm{P}=0.033)$. However, the results indicated that knowledge hoarding did not moderate the effect of knowledge management processes on innovation performance $($ Estimate $=0.036, C . R .=1.12$, $\mathrm{P}=0.262)$.

Table 7

Results of hypotheses testing

\begin{tabular}{cccccc}
\hline Path & Estimate & S.E. & C.R. & P-value & Result \\
\hline KM processes $\rightarrow$ IP & 0.367 & 0.108 & 3.170 & 0.000 & Supported \\
KH $\rightarrow$ IP & -0.228 & 0.107 & 2.135 & 0.033 & Supported \\
Interaction $\rightarrow$ IP & 0.036 & 0.032 & 1.121 & 0.262 & Rejected \\
\hline
\end{tabular}

\section{Discussion and conclusion}

The aim of this study was to explore the effect of KM processes (knowledge acquisition, dissemination, storage, sharing and application) on innovation performance and to investigate the moderating role of knowledge hoarding on the effect on the independent variable on the dependent one. The results have indicated that each process of KM processes exerts a positive significant effect on innovation performance. Numerous studies have already confirmed these results. The results of Darroch and McNaughton (2002) indicated that knowledge acquisition is positively related to innovation. Lin (2007) found that knowledge collecting and sharing had significant effects on firm's innovation capability. For Alegre et al. (2011), KM practices as measured by knowledge dissemination and storage had a significant effect on innovation performance. Chen and Huang (2009) confirmed that knowledge acquisition, sharing and application, etc. The results showed that knowledge dissemination is the least effective process in improving innovation. This result is in agreement with Darroch and McNaughton (2002) who found that knowledge acquisition is more important for innovation than knowledge dissemination. Furthermore, the results showed that KM processes as a whole had a positive and significant effect on innovation performance. A similar result was depicted by Du Plessis (2007). The results revealed a significant negative effect of knowledge hoarding on innovation performance. Holten et al. (2016) regarded knowledge hoarding as a result of lack of trust between employees. This result is logical because knowledge hoarding works in an opposite way to share knowledge (Aulawi et al., 2009).

In addition, knowledge hoarding did not exert a moderating effect on the impact of KM processes as an independent variable on innovation performance as a dependent variable. The moderating role of knowledge hoarding on the effect of KM processes on innovation performance has not been tested before. However, studies have shown that employees should be encouraged to abandon the behavior of knowledge hoarding and shift to knowledge sharing in order to achieve good outcomes for the firm such as sustainable competitiveness (Pillania, 2006). In conclusion, despite the negative role of knowledge hoarding on innovation performance, this role has no considerable impact on the relationship between knowledge management processes and innovation performance. This may be due to the fact that the knowledge hoarded by employees is not related to improving innovation. The organization should therefore focus on the nature of knowledge held by the employee and verify its role in improving innovation. 


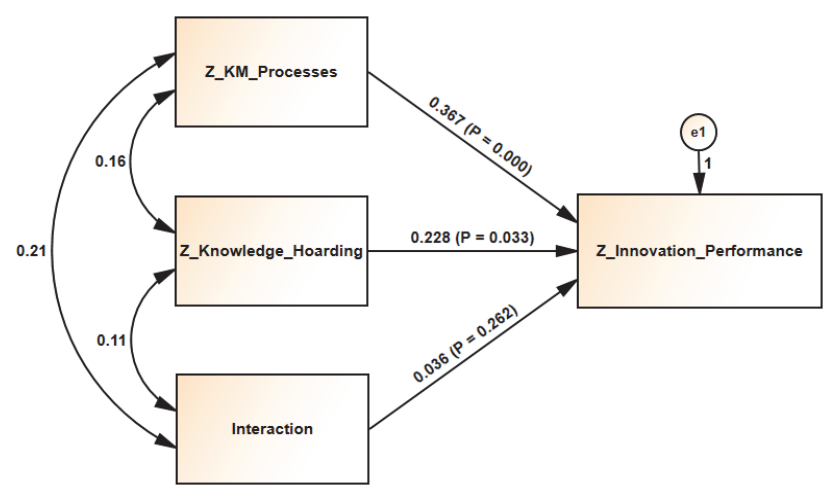

Fig. 3. Hypothesis testing results

\section{Limitations and recommendations}

This study was limited to data collection method that conducted using a questionnaire. Other tools are recommended to collect data. On the other hand, the study is cross-sectional, as the data were collected in a single period of time. In this regard, it is possible to carry out longitudinal studies by collecting data over a period of time. In terms of knowledge management processes, five dimensions were used in the current study, which were knowledge acquisition, dissemination, storage, sharing and application. Hence, future studies should investigate these and other processes in order to investigate their effect on innovation performance. Knowledge hoarding was measured by items related to knowledge accumulation, knowledge share refuse, and "knowledge is power" syndrome, consequently, additional items should be used to assess knowledge hoarding. Finally, it is recommended that future studies should consider other variables that have an effect on innovation performance such as organization size (Rupietta \& Backes-Gellner, 2019).

\section{References}

Alegre, J., Sengupta, K., \& Lapiedra, R. (2011). Knowledge management and innovation performance in a high-tech SMEs industry. International Small Business Journal, 31(4), 454-470.

Al-Hakim, L., \& Shahizan, H. (2011). The role of middle managers in knowledge management implementation for innovation enhancement. International Journal of Innovation, Management and Technology, 2(1), 86-94.

Al-Husseini, S., \& Elbeltagi, I. (2015). Knowledge sharing practices as a basis of product innovation: A case of higher education in Iraq. International Journal of Social Science and Humanity, 5(2), 182-185.

Anaza, N., \& Nowlin, E. (2017). What's mine is mine: A study of salesperson knowledge withholding \& hoarding behavior. Industrial Marketing Management, 64, 14-24.

Arshad, R., \& Ismail, I. (2018). Workplace incivility and knowledge hiding behavior: does personality matter?. Journal of Organizational Effectiveness: People and Performance, 5(3), 278-288.

Aulawi, H., Sudirman, I., Suryadi, K., \& Govindaraju, R. (2009). Knowledge sharing behavior, antecedent and their impact on the individual innovation capability. Journal of Applied Sciences Research, 5(12), 2238-2246.

Barley, W., Treem, J., \& Kuhn, T. (2018). Valuing multiple trajectories of knowledge: A critical review and agenda for knowledge management research. Academy of Management Annals, 12(1), 278-317.

Bilginoğlu, E. (2019). Knowledge hoarding: A literature review. Management Science Letters, 9(1), 61-72.

Birkinshaw, J., \& Sheehan, T. (2002). Managing the knowledge life cycle. MIT Sloan management review, 44(1), 75-84.

Blome, C., Schoenherr, T., \& Eckstein, D. (2014). The impact of knowledge transfer and complexity on supply chain flexibility: A knowledge-based view. International Journal of Production Economics, 147, 307-316.

Bock, G., Zmud, R., Kim, Y., \& Lee, J. (2005). Behavioral intention formation in knowledge sharing: Examining the roles of extrinsic motivators, social-psychological forces, and organizational climate. MIS Quarterly, 29(1), 87-111.

Chapman, R., \& Magnusson, M. (2006). Continuous innovation, performance and knowledge management: an introduction. Knowledge and Process Management, 13(3), 129-131.

Chen, C., \& Huang, J. (2009). Strategic human resource practices and innovation performance - The mediating role of knowledge management capacity. Journal of Business Research, 62(1), 104-114.

Connelly, C., Zweig, D., Webster, J., \& Trougakos, J. (2012). Knowledge hiding in organizations. Journal of Organizational Behavior, 33(1), 64-88.

Darroch, J. (2005). Knowledge management, innovation and firm performance. Journal of Knowledge Management, 9(3), 101-115.

Darroch, J., \& McNaughton, R. (2002). Examining the link between knowledge management practices and types of innovation. Journal of Intellectual Capital, 3(3), 210-222.

Donate, M., \& de Pablo, J. (2015). The role of knowledge-oriented leadership in knowledge management practices and innovation. Journal of Business Research, 68(2), 360-370. 
Du Plessis, M. (2005). Drivers of knowledge management in the corporate environment. International Journal of Information Management, 25(3), 193-202.

Du Plessis, M. (2007). The role of knowledge management in innovation. Journal of Knowledge Management, 11(4), $20-29$.

Fornell, C., \& Larcker, D. (1981). Evaluating structural equation models with unobservable and measurement error. Journal of Marketing Research, 18(1), 39-50

Garrido-Moreno, A., \& Padilla-Meléndez, A. (2011). Analyzing the impact of knowledge management on CRM success: The mediating effects of organizational factors. International Journal of Information Management, 31(5), 437-444.

Gloet, M., \& Terziovski, M. (2004). Exploring the relationship between knowledge management practices and innovation performance. Journal of Manufacturing Technology Management, 15(5), 402-409.

Holten, A., Robert Hancock, G., Persson, R., Marie Hansen, Å., \& Høgh, A. (2016). Knowledge hoarding: antecedent or consequent of negative acts? The mediating role of trust and justice. Journal of Knowledge Management, 20(2), 215-229.

Husted, K., \& Michailova, S. (2002). Diagnosing and fighting knowledge-sharing hostility. Organizational Dynamics, 31(1), 60-73.

Iqbal, A. (2011). Creativity and innovation in Saudi Arabia: An overview. Innovation, 13(3), 376-390.

Karamat, J., Shurong, T., Ahmad, N., Waheed, A., \& Khan, S. (2018). Barriers to knowledge management in the health sector of Pakistan. Sustainability, 10(11), 4155.

Kör, B., \& Maden, C. (2013). The relationship between knowledge management and innovation in Turkish service and high-tech firms. International Journal of Business and Social Science, 4(4), 293-304.

Lin, H. (2007). Knowledge sharing and firm innovation capability: an empirical study. International Journal of Manpower, 28(3/4), 315-332.

Loon, M. (2019). Knowledge management practice system: Theorizing from an international meta-standard. Journal of Business Research, 94, 432-441.

Mahdi, O., Nassar, I., \& Almsafir, M. (2019). Knowledge management processes and sustainable competitive advantage: An empirical examination in private universities. Journal of Business Research, 94, 320-334.

Masa'deh, R., Shannak, R., Maqableh, M., \& Tarhini, A. (2017). The impact of knowledge management on job performance in higher education: The case of the University of Jordan. Journal of Enterprise Information Management, 30(2), $244-262$.

Mauri-Castello, J., Alonso-Gonzalez, A., \& Peris-Ortiz, M. (2019). Applied innovation methodology: A proposal for a dynamic sustainable environment for the generation of innovation and knowledge management practices in SMEs. In: Peris-Ortiz, M., Ferreira, J., Merigó-Lindahl, J. (eds) Knowledge, Innovation and Sustainable Development in Organizations. Innovation, Technology, and Knowledge Management. Springer, Cham

Mundra, N., Gulati, K., \& Vashisth, R. (2011). Achieving competitive advantage through knowledge management and innovation: Empirical evidences from the Indian IT sector. IUP Journal of Knowledge Management, 9(2), 7-25

Obeidat, B., Al-Suradi, M., Masa'deh, R., \& Tarhini, A. (2016). The impact of knowledge management on innovation: An empirical study on Jordanian consultancy firms. Management Research Review, 39(10), 1214-1238.

Okur N., \& Saricam C. (2019) The Impact of Knowledge on Consumer Behaviour Towards Sustainable Apparel Consumption. In: Muthu, S. (eds) Consumer Behaviour and Sustainable Fashion Consumption. Textile Science and Clothing Technology. Springer, Singapore

Pillania, R. (2006). Leveraging knowledge for sustainable competitiveness in SMEs. International Journal of Globalization and Small Business, 1(4), 393-406.

Prabhakar, G., Reddy, P., Savinkina, L., Gantasala, S., \& Ankireddy, S. (2018). Influence of organizational culture dimensions on knowledge management processes in higher educational institutions. International Journal of Knowledge Management Studies, $9(1), 51-71$.

Rasula, J., Vuksic, V., \& Stemberger, M. (2012). The impact of knowledge management on organizational performance. Economic and Business Review for Central and South-Eastern Europe, 14(2), 147.

Rezaei, A., Allameh, S. M., \& Ansari, R. (2018). Impact of knowledge creation and organisational learning on organisational innovation: an empirical investigation. International Journal of Business Innovation and Research, 16(1), 117-133.

Robinson, C., \& Schumacker, R. E. (2009). Interaction effects: centering, variance inflation factor, and interpretation issues. Multiple Linear Regression Viewpoints, 35(1), 6-11.

Rupietta, C., \& Backes-Gellner, U. (2019). Combining knowledge stock and knowledge flow to generate superior incremental innovation performance-Evidence from Swiss manufacturing. Journal of Business Research, 94, 209-222.

Sadikoglu, E. and Zehir, C. (2010). Investigating the effects of innovation and employee performance on the relationship between total quality management practices and firm performance: An empirical study of Turkish firms. International Journal of Production Economics, 127(1), 13-26.

Salem, I. (2014). Toward better understanding of knowledge management: Correlation to hotel performance and innovation in five-star chain hotels in Egypt. Tourism and Hospitality Research, 14(4), 176-196.

Santos, J. (1999). Cronbach's alpha: A tool for assessing the reliability of scales. Journal of Extension, 37(2), 1-5.

Scarbrough, H. (2003). Knowledge management, HRM and the innovation process. International Journal of Manpower, 24(5), 501516.

Seidler-de Alwis, R., \& Hartmann, E. (2008). The use of tacit knowledge within innovative companies: knowledge management in innovative enterprises. Journal of knowledge Management, 12(1), 133-147.

Sivo, S., Fan, X., Witta, E., \& Willse, J. (2006). The search for "optimal" cutoff properties: Fit index criteria in structural equation modeling. The Journal of Experimental Education, 74(3), 267-288. 
Srivastava S.K., Chandra B., \& Srivastava P. (2019). The impact of knowledge management and data mining on CRM in the service industry. In: Nath, V., Mandal, J. (eds) Nanoelectronics, Circuits and Communication Systems. Lecture Notes in Electrical Engineering, vol., 511. Springer, Singapore

Yang, J. (2007). Knowledge sharing: Investigating appropriate leadership roles and collaborative culture. Tourism Management, 28(2), 530-543.

Yoo, B., \& Donthu, N. (2001). Developing a scale to measure the perceived quality of an Internet shopping site(SITEQUAL). Quarterly Journal of Electronic Commerce, 2(1), 31-45.

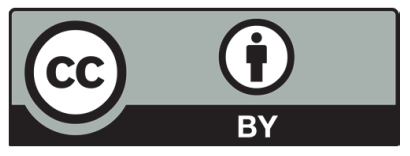

(C) 2020 by the authors; licensee Growing Science, Canada. This is an open access article distributed under the terms and conditions of the Creative Commons Attribution (CC-BY) license (http://creativecommons.org/licenses/by/4.0/). 